\title{
Creating and Managing Value in Collaborative Networks
}

\author{
Umit S Bititci, Veronica Martinez, Pavel Albores and Joniarto Parung \\ Centre for Strategic Manufacturing \\ DMEM, University of Strathclyde, Glasgow, UK
}

\begin{abstract}
This is a theoretical paper that examines the interplay between individual and collective capabilities and competencies and value transactions in collaborative environments. The theory behind value creation is examined and two types of value are identified, internal value (Shareholder value) and external value (Value proposition). The literature on collaborative enterprises/network is also examined with particular emphasis on supply chains, extended/virtual enterprises and clusters as representatives of different forms and maturities of collaboration. The interplay of value transactions and competencies and capabilities are examined and discussed in detail. Finally, a model is presented which consists of value transactions and a table which compares the characteristics of different types of collaborative enterprises/networks. It is proposed that this model presents a platform for further research to develop an in-depth understanding into how value may be created and managed in collaborative enterprises/networks.
\end{abstract}

Keywords: value, value propositions, collaboration, supply chain, extended enterprise, clusters. 
Bititci, Martinez, Albores and Parung, 2004, Creating and Managing Value in Collaborative Networks, International Journal of Physical Distribution and Logistics Management, issue 3/4, 2004.

\section{Introduction}

In today's global economy, companies are trying to re-invent their businesses and maintain their competitive advantage through collaboration. Collaborative practices such as supply chains, value chains, extended enterprises, virtual enterprises and clusters are becoming commonplace. However, collaboration for collaboration sake is not enough; if businesses are to maintain their competitive advantage and continue to sustain their performance, collaboration should result in creation of new and unique value propositions based on a unified approach to value creation.

The proposition underpinning the work presented in this paper is that value creation in collaborative organisations should be a win-win-win situation for all parties concerned. To this end, the purpose of this paper is to develop a better understanding of value creation and the role of value propositions in collaborative networks such as supply chains, extended/virtual enterprises and clusters. This is achieved by examining the theory behind value creation and value propositions in the context of different collaborative enterprises/networks. As a conclusion a comparison of different collaborative enterprises/networks is presented with particular emphasis on the different value transactions and their relationship with individual and collective capabilities and competencies.

\section{Value}


Bititci, Martinez, Albores and Parung, 2004, Creating and Managing Value in Collaborative Networks, International Journal of Physical Distribution and Logistics Management, issue 3/4, 2004.

Today, the concept of value is of increasing interest to both academics and practitioners in different fields such as economics, operations management, marketing, construction management and so on. As a result there are a large number of definitions for the term "value".

In order to have a better understanding of value in the context of collaboration, we have to link two perspectives of value (Martinez, 2003). These are:

- Internal value, i.e. shareholder perspective, where value = wealth

- External value, i.e. customer perspective, where value $=$ satisfaction

According to Martinez (2003) "Value resides in the satisfaction and fulfilment of customers' expectations, at the same time, generating wealth for organisations."

In other words, an organisation in satisfying it's customers' expectations, should be creating wealth for its shareholders; hence creating value for both parties. Accordingly, value creation in collaborative organisations should be a win-win-win situation for all parties concerned. The partners should each benefit from collaboration by increasing internal value to their shareholders as well as delivering better value (external) to the endcustomer.

The generic value propositions presented in the Value Matrix (Martinez and Bititci, 2001) have shown a focused way to guide organisations for creating unique value. This is because the value proposition differentiates from the traditional view of value (internal- 
Bititci, Martinez, Albores and Parung, 2004, Creating and Managing Value in Collaborative Networks, International Journal of Physical Distribution and Logistics Management, issue 3/4, 2004.

oriented view) by looking at the business from a customer perspective (external oriented view).

\section{Value Propositions}

The value proposition is defined as "an implicit promise a company makes to its customers to deliver a particular combination of values" (Martinez, 2003). Each proposition searches for a unique value that can be delivered to a chosen market. Successful companies do not just add value, they re-invent it.

The application of this concept has changed the focus of operations in many businesses by redefining their competencies and capabilities (e.g. IBM, DELL, ICI, Federal Express). In doing so, these companies have also made some fundamental decisions on customer segmentation, competencies, culture, infrastructure, technology, resources and strategies (O’Dell and Grayson, 1999).

The Value Matrix (Martinez and Bititci, 2001), illustrated in Figure 1, proposes six generic value propositions. These value propositions are an extension of the three original value propositions proposed by Treacy and Wiersema (1996) by introduction of the new value dimension, i.e Hard Value and Soft Value. Table 1 explains each value proposition from the customer perspective as "Customers get" and company perspective as "Company needs to do". 
Bititci, Martinez, Albores and Parung, 2004, Creating and Managing Value in Collaborative Networks, International Journal of Physical Distribution and Logistics Management, issue 3/4, 2004.

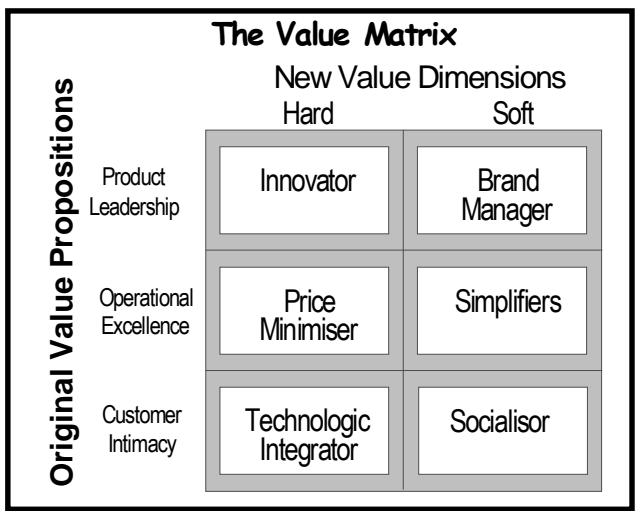

Figure 1. The Value Matrix

Table 1. Six generic value proposition of the Value Matrix

\begin{tabular}{|c|c|c|c|}
\hline \multirow{2}{*}{$\begin{array}{c}\text { Value } \\
\text { Proposition }\end{array}$} & \multirow{2}{*}{$\begin{array}{c}\text { What the } \\
\text { customers get? }\end{array}$} & \multicolumn{2}{|c|}{ What the company needs to do? } \\
\hline & & Strategic Objectives & Operational Objectives \\
\hline $\begin{array}{l}\text { Innovators } \\
\text { Intel, Sony }\end{array}$ & $\begin{array}{l}\text { New innovative } \\
\text { designs and products } \\
\text { never seen before. }\end{array}$ & $\begin{array}{l}\text { Continuous stream of } \\
\text { breakthrough designs and } \\
\text { products with new and } \\
\text { unique features. Often } \\
\text { technologically oriented. }\end{array}$ & $\begin{array}{l}\text { Long-term vision, robust } \\
\text { R\&D and product } \\
\text { development capability. } \\
\text { Capacity to innovate within } \\
\text { short product lifecycles. }\end{array}$ \\
\hline $\begin{array}{l}\text { Brand Managers } \\
\text { Harley Davidson, } \\
\text { Nike, Highland } \\
\text { Spring }\end{array}$ & $\begin{array}{l}\text { Product status } \\
\text { Lifestyle statement } \\
\text { A feeling of } \\
\text { superiority } \\
\end{array}$ & $\begin{array}{l}\text { Global brand recognition } \\
\text { Reinforce solid brand image } \\
\text { of the product and/or } \\
\text { company. }\end{array}$ & $\begin{array}{l}\text { Focus market sector. } \\
\text { Superior control over the } \\
\text { product styles, quality and } \\
\text { promotion. }\end{array}$ \\
\hline $\begin{array}{l}\text { Price } \\
\text { Minimisers } \\
\text { Nissan } \\
\text { Price/Costco } \\
\text { Tesco } \\
\end{array}$ & $\begin{array}{l}\text { Ordinary, reliable } \\
\text { products and services } \\
\text { at low prices. }\end{array}$ & $\begin{array}{l}\text { Highly effective production } \\
\text { and logistics capability with } \\
\text { high quality levels and low } \\
\text { waste. }\end{array}$ & $\begin{array}{l}\text { Highly efficient and } \\
\text { effective order fulfilment } \\
\text { process sustained by product } \\
\text { standardisation. Automation } \\
\text { and proceduralisation. }\end{array}$ \\
\hline $\begin{array}{l}\text { Simplifiers } \\
\text { Screwfix direct } \\
\text { Houston } w / h \\
\text { Easyjet }\end{array}$ & $\begin{array}{l}\text { Convenience and } \\
\text { availability of the } \\
\text { products. } \\
\text { Hassle free } \\
\text { experience. }\end{array}$ & $\begin{array}{l}\text { Building streamlined } \\
\text { processes to make life } \\
\text { simple and uncomplicated } \\
\text { for customers in a novel and } \\
\text { profitable way. }\end{array}$ & $\begin{array}{l}\text { Availability and } \\
\text { accessibility. Effective order } \\
\text { fulfilment-distribution by } \\
\text { conventional and un- } \\
\text { conventional resources } \\
\text { (networking, IT, etc.). }\end{array}$ \\
\hline $\begin{array}{l}\text { Technological } \\
\text { Integrator } \\
\text { Alcan specialist } \\
\text { chemicals }\end{array}$ & $\begin{array}{l}\text { Tailored products and } \\
\text { services. } \\
\text { Total solutions. }\end{array}$ & $\begin{array}{l}\text { Tailor specific and } \\
\text { continuous solutions for } \\
\text { carefully selected customers } \\
\text { on the basis of permanent } \\
\text { relationships. }\end{array}$ & $\begin{array}{l}\text { Understanding customers } \\
\text { business, markets, products } \\
\text { and operations. Capacity to } \\
\text { configure products and } \\
\text { services. Ability to adopt the } \\
\text { customer's strategy. }\end{array}$ \\
\hline $\begin{array}{l}\text { Socialisors } \\
\text { Small } \\
\text { consultancies and } \\
\text { tradesman }\end{array}$ & $\begin{array}{l}\text { Flexible services and } \\
\text { inter-personal } \\
\text { relationship built and } \\
\text { trust. }\end{array}$ & $\begin{array}{l}\text { Build confidence and trust } \\
\text { with customers through } \\
\text { understanding of their } \\
\text { business needs. }\end{array}$ & $\begin{array}{l}\text { Sensitive fulfilment of } \\
\text { customers' needs supported } \\
\text { by careful deliver, } \\
\text { reliability, and honesty. } \\
\text { Excellent personal service. }\end{array}$ \\
\hline
\end{tabular}


Bititci, Martinez, Albores and Parung, 2004, Creating and Managing Value in Collaborative Networks, International Journal of Physical Distribution and Logistics Management, issue 3/4, 2004.

The works of Treacy and Wiersema (1996) and Martinez and Bititci (2001) highlight the following pertinent points:

- Most successful companies have a very clear and unambiguous value proposition/ offering to their customers, which forms the basis of their business and operations strategies.

- These value propositions are a function of carefully shaped and honed competencies where each firm has focused on developing the key competencies and capabilities that enable them to deliver their value proposition to their customers efficiently and effectively ensuring that internal value (i.e. shareholder) expectations are also satisfied.

- The value proposition is the common ground between the customer and the supplier.

So far, the concept of the value proposition has been applied at a single enterprise level to link the customers' expectations with the suppliers offer. However, if collaboration is to result in creation of new and unique value propositions based on a unified approach to value creation, then the role of value propositions in collaborative networks needs to be better understood.

\section{Collaboration}

Collaboration literally means working-together (Huxham, 1996, Jordan Jr. and Michel, 2000). The term is often used when individuals or organisations work together towards a common aim. The other terms that are used to describe this situation are relationships, partnerships or alliances. 
Bititci, Martinez, Albores and Parung, 2004, Creating and Managing Value in Collaborative Networks, International Journal of Physical Distribution and Logistics Management, issue 3/4, 2004.

Collaboration has been discussed as a way forward for organisations in situations in which working alone is not sufficient to achieve the desired ends (Huxham, 1996). Most definitions of collaboration are based on this assumption as follows. Collaboration is:

- taken to imply a very positive form of working in association with others for some form of mutual benefit (Huxham, 1996).

- a distinct mode of organising, implies a positive, purposeful relationship between organisations that retain autonomy, integrity and distinct identity, and thus, the potential to withdraw from the relationship (Huxham, 1996).

- a number of companies linked to create and support a service or product for its service life including final disposal (Jordan and Michel, 2000).

- a focus on joint planning, coordination and process integration between supplier, customers and others partners in a supply chain. Also involves strategic joint decision making about partnership and network design (McLaren et al, 2002).

- a process in which organizations exchange information, alter activities, share resources and enhance each other's capacity for mutual benefit and a common purpose by sharing risks, responsibilities and rewards' (Himmelman, 1992 in Huxham, 1996).

\section{Collaboration: Motives and Benefits}

The literature on collaboration suggests that implementation of collaborative initiatives has inherited difficulties; therefore the amount of effort involved in integrating operational, tactical or strategic levels of separate companies is usually large. However, the same literature also reports that the benefits of such collaboration are considered to be 
Bititci, Martinez, Albores and Parung, 2004, Creating and Managing Value in Collaborative Networks, International Journal of Physical Distribution and Logistics Management, issue 3/4, 2004.

significant. Some motives and benefits associated with inter-enterprise collaboration have been identified as:

- To increase their market share (Lewis, 1990).

- To increase asset utilization (Lewis, 1990).

- To enhance customer service - reduction in lead times, customer complaints, etc. (Lewis, 1990).

- To share and reduce the cost of product development (Lewis, 1990; Parker,2000; Horvarth, 2001; McLaren et al., 2002)

- To reduce time in product development (Lewis, 1990; Parker, 2000; McCarthy and Golicic, 2002,McLaren et al., 2002;)

- To decrease risk of failure of product development (Parker,2000)

- To increase quality of product (Lewis, 1990)

- To enhance skill and knowledge (Lewis, 1990)

- To have technological gain as participating firm (Lewis, 1990; Parker, 2000)

- To achieve economies of scale in production (Lewis, 1990)

- To reduce inventory - in the face of increasing technological complexity and rapid rate product development and obsolescence (Parker, 2000, Holton,2001)

- To gain rapid access to markets (Parker, 2000; McCarthy and Golicic, 2002)

In context of the research proposition that underpins this paper, collaboration should lead to a win-win-win situation for all parties concerned (i.e participating partners as well as the end-customer). There is no doubt that the motivation for each individual enterprise comes not from the fact that they want to collaborate but from the fact that there are 
Bititci, Martinez, Albores and Parung, 2004, Creating and Managing Value in Collaborative Networks, International Journal of Physical Distribution and Logistics Management, issue 3/4, 2004.

economic advantages to be gained through collaboration. But what about the end customer? How does or should the combined competencies of participating partners affect the value proposition of the collaborative enterprise to the end-customer?

In order to provide logical answers to these questions it is necessary to understand the literature relating to collaborative networks such as supply chains, extended enterprises, virtual enterprises and clusters.

\section{Collaborative Networks and Value Propositions}

In this paper, we argue that the type of value created and obtained by a specific collaboration is dependent on the degree of maturity of that collaboration. A framework to describe the maturity of the collaboration is proposed by Childerhouse et al (2003), which presents five stages of maturity: Ad hoc, Defined, Linked, Integrated and Extended. Although this model is focused primarily on supply chains, the different stages of maturity for collaborative enterprises may be categorised as:

- Ad hoc - collaboration does not go beyond the traditional customer supplier relationship.

- Defined and Linked - collaboration focuses on operational issues and limited to collaborative planning, forecasting and replenishment of materials and capacities, i.e. Supply Chain Management.

- Integrated + Extended- collaboration at a strategic level where integrated and coordinated strategies lead to strategic synergy, i.e. Extended and Virtual Enterprises. 
Bititci, Martinez, Albores and Parung, 2004, Creating and Managing Value in Collaborative Networks, International Journal of Physical Distribution and Logistics Management, issue 3/4, 2004.

- To this spectrum of maturity, we would also add Clusters, which represent integrated collaborations which also include supporting infrastructures.

The following sections provide a more detailed discussion on how the combined competencies of participating partners can affect and shape the value proposition of typical collaborative networks, such as supply chains, extended enterprises, virtual enterprises and clusters. In doing so, the "value transactions" across the network, in which value is promised, planned, managed and delivered, are identified as well as highlighting the differences that this has for companies working in different collaborative networks.

\subsection{Supply Chains}

During the last decade, companies have started to have awareness of the need to take into account their suppliers and customers. Traditionally, the focus has been on the supply chain in order to manage the movement of materials from suppliers to end customer efficiently and effectively. Supply chain management models such as SCOR (Supply Chain Operations Reference model - www.supply-chain.org) identify the need for external integration between the supply chain partners. But this integration remains at an operational level. At best, supply chains are about collaborative planning, fulfilment and replenishment (CPFR), but do not achieve the level of strategic collaboration and synergy along the supply chain. 
Bititci, Martinez, Albores and Parung, 2004, Creating and Managing Value in Collaborative Networks, International Journal of Physical Distribution and Logistics Management, issue 3/4, 2004.

Essentially, in supply chains, each company plans its operations according to the orders received and forecasted and commits capacities and delivery dates according to their individual loads and capacities. Accordingly, strategy for companies in the supply chain is formulated at the enterprise level, not at the supply chain level. Generally, the analysis of supply chains has taken place from the point of view of one of the members of the supply chain and not for the supply chain as a whole, trying to improve the "supply chain related processes" of a single company, rather than really optimising the whole of the supply chain. This issue is found repeatedly in the literature, e.g. Darroch et al., (2002) and Rudberg and Olhager (2003) present studies of value and strategy from the point of view of different partners in the SC, but do not consider the collaborative system as a whole.

Some authors have described the need to align the members of the supply chain in order to gain better performance (e.g. Carbo, 2002). Childerhouse et al, (2002) and Eloranta (1999) propose the analysis of demand chains in order to achieve better performance in the demand chain. However, the approach is still centred on the individual company, rather than on the $\mathrm{SC}$ as a whole.

Taking the view of supply chain management as simply the management of the logistics operations of a company, both upstream and downstream, we can see that the value propositions of the supply chain members are disjointed, focusing on delivering value to the next member in the chain, and not worrying about the overall value proposition that is important to the end customer. 
Bititci, Martinez, Albores and Parung, 2004, Creating and Managing Value in Collaborative Networks, International Journal of Physical Distribution and Logistics Management, issue 3/4, 2004.

Figure 2 illustrates the value propositions that emerge in supply chain type collaborations where the companies in the supply chain select their individual value proposition, aligning it to the next member of the supply chain. In this case, the value proposition of the overall supply chain is the same as that of the company that is facing the end customer $\left(\mathrm{E}_{3}\right.$ in Figure 2) - that is the value proposition is a function $(f)$ of the competences and capabilities of that last company in the chain.

$$
\mathrm{VP}_{\mathrm{SC}}=\mathrm{VP}_{\mathrm{E} 3}=f\left(\mathrm{CC}_{\mathrm{E} 3}\right)
$$

$\mathrm{VP}_{\mathrm{SC}}-$ Value proposition of the supply chain

$\mathrm{VP}_{\mathrm{E} 3}$ - Value proposition of Enterprise \#3

$\mathrm{CC}_{\mathrm{E} 3}-$ Competencies and capabilities of Enterprise \#3

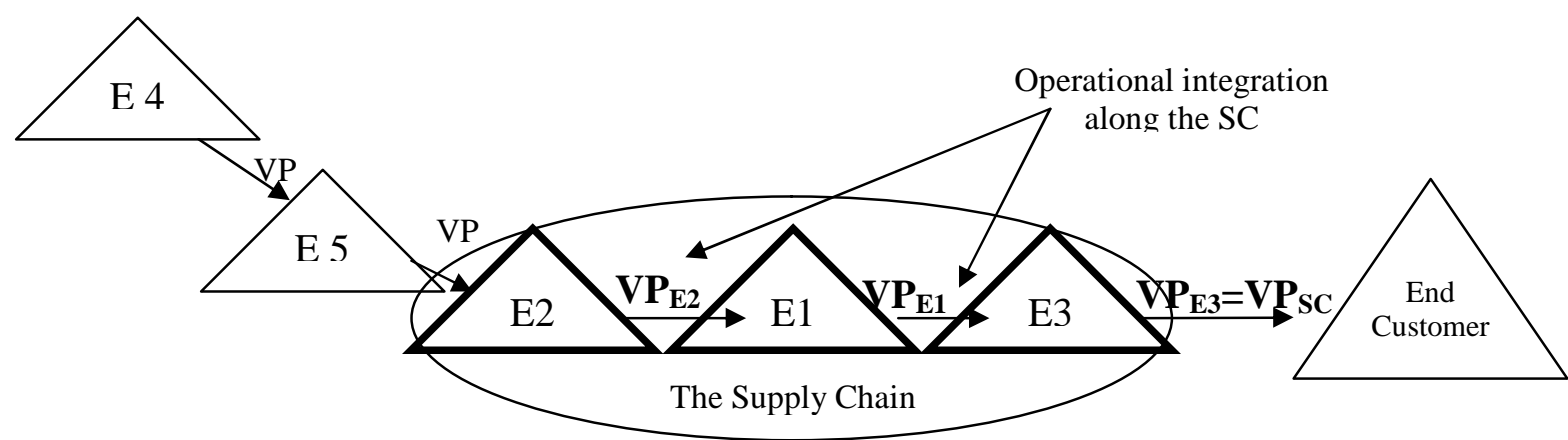

Figure 2. Value propositions (VP) in supply chains

\subsection{Extended and Virtual Enterprises}

According to Childe (1998) an extended enterprise is 'a conceptual business unit or system that consists of a purchasing company and suppliers who collaborate closely in such a way as to maximise the returns to each partner'.

In this paper, the virtual enterprise is considered as a temporal case of an extended enterprise. I.e. the virtual enterprise is a dynamic partnership among companies that can 
Bititci, Martinez, Albores and Parung, 2004, Creating and Managing Value in Collaborative Networks, International Journal of Physical Distribution and Logistics Management, issue 3/4, 2004.

bring together complementary competencies needed to achieve a particular business task, within a certain period of time (Kochhar and Zang, 2002).

From the literature on extended and virtual enterprises the following pertinent points have been extracted as being of relevance to the research presented in this paper:

- The extended enterprise is a philosophy where member organisations strategically combine their core competencies and capabilities to create a unique competency. A facet of this approach is the development of products and services that best fit the physical and intellectual characteristic of the individual markets (Martinez et al. 2001, Kochhar and Zhang 2002).

- In extended enterprises, people across a number of organisations participate in the decision-making process. This demands knowledge and resource integration (O’Neill and Sackett 1994).

- In an extended enterprise each company is self-organised, while the extended enterprise imposes a federal structure for communication and synchronisation between individual enterprises (Martinez et al. 2001).

- The Extended Enterprise business strategy formulation is an incremental process; planning, implementation, evaluation and revision represent small steps, done almost simultaneously (Martinez et al. 2001, Lillehagen and Karlsen 2001). 
Bititci, Martinez, Albores and Parung, 2004, Creating and Managing Value in Collaborative Networks, International Journal of Physical Distribution and Logistics Management, issue 3/4, 2004.

In a supply chain, each participating company operating as an individual enterprise tries to maximise its own corporate goals, thus sub-optimising the overall performance. An extended enterprise is a chain of enterprises, which essentially behave as a single enterprise trying to maximise the corporate goals of the extended enterprise, thus optimising the performance of each individual enterprise (Bititci et al, 2003). This difference is illustrated in Figure 3. The serial and parallel configuration of the extended enterprise is determined by its needs, i.e. competencies, capabilities and resources.

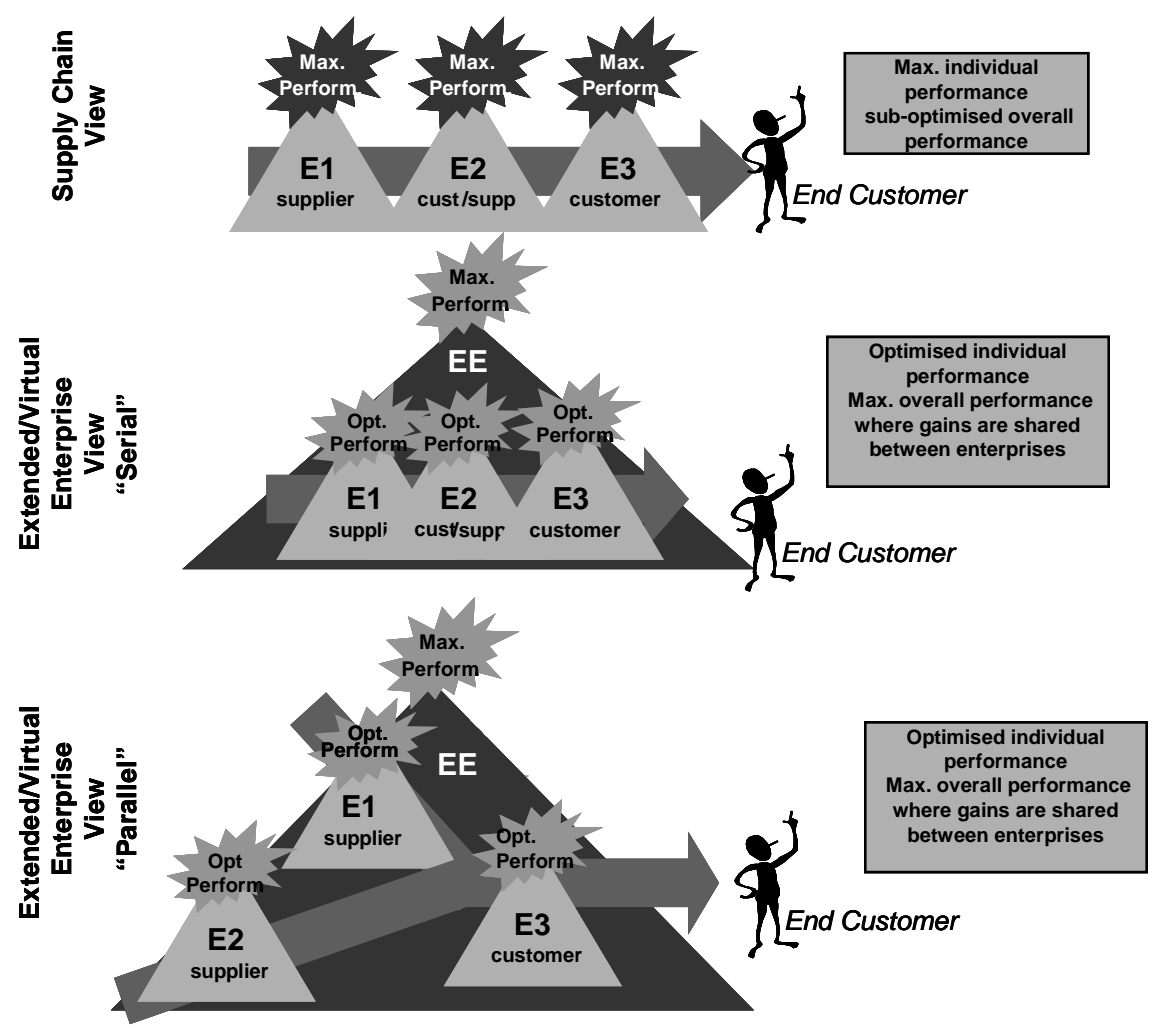

Figure 3. Extended enterprise (serial \& parallel collaborations) Vs. supply chain 
Bititci, Martinez, Albores and Parung, 2004, Creating and Managing Value in Collaborative Networks, International Journal of Physical Distribution and Logistics Management, issue 3/4, 2004.

Based on this literature, we propose the following definitions:-

- 'An Extended Enterprise is a knowledge-based organisation, which uses the distributed capabilities, competencies and intellectual strengths of its members to gain competitive advantage to maximise the performance of the overall extended enterprise'

- 'A Virtual Enterprise is a temporal knowledge-based organisation, which uses the distributed capabilities, competencies and intellectual strengths of its members to gain competitive advantage to maximise the performance of the overall virtual enterprise'

In the extended/virtual enterprise, there is a strong integration of the actors' value propositions. The whole extended/virtual enterprise follows a common value proposition that is focused on the delivery of a specific value for a selected market (end customer). It is characterised by its strategic and operational collaboration.

The integration of the value proposition's actors implies that the individual competencies and capabilities (CC) are integrated and complement each other, thus they are aligned to 'the overall value proposition of the extended/virtual enterprise' to create a particular value for the end customers.

$$
\mathrm{VP}_{\mathrm{EE}}=f\left(\mathrm{CC}_{\mathrm{EE}}\right) \geq\left[\mathrm{CC}_{\mathrm{E} 1}+\mathrm{CC}_{\mathrm{E} 2}+\mathrm{CC}_{\mathrm{E} 3}+\ldots .+\mathrm{CC}_{\mathrm{En}}\right]
$$


Bititci, Martinez, Albores and Parung, 2004, Creating and Managing Value in Collaborative Networks, International Journal of Physical Distribution and Logistics Management, issue 3/4, 2004.

$\mathrm{VP}_{\mathrm{EE}}=$ Value Proposition of the extended/virtual enterprise

$\mathrm{CC}_{\mathrm{EE}}=$ Collective competencies and capabilities of the extended/virtual enterprise

$\mathrm{CC}_{\mathrm{En}}=$ Individual competencies and capabilities of the participating companies

In the literature the basic assumption is that collaboration takes place between individual companies/enterprises. However, according to the empirical evidence provided by Bititci et al (2003), the architecture of the extended enterprise is somewhat more complex then the one illustrated in Figure 3. The critical points are that:

- Extended/virtual enterprises emerge as a result of collaboration between business units of companies, rather than whole companies.

- One company could be participating in more than one extended enterprise

The extended enterprise shown in Figure 4 is formed by the business units of three enterprises, i.e. BU1, BU2 and BU3 (illustrated with the solid-white arrows). This figure shows the value proposition of the $\mathrm{EE}\left(\mathrm{VP}_{\mathrm{EE}}\right)$ at the top of the $\mathrm{EE}$ triangle, it is supported by the value propositions of its actors (VP1, VP2 and VP3).

The value proposition of the extended enterprise is determined by a meta-level management process, which plans, co-ordinates and reviews the value creation process of the entire extended enterprise to achieve strategic and operational synergy. A function of this meta-manage process is to ensure that strategic synergy is maintained between the members of the extended enterprise by ensuring the individual capabilities and competencies (therefore the individual value propositions) of each business unit is aligned with the value proposition of the extended enterprise. In achieving this strategic 
Bititci, Martinez, Albores and Parung, 2004, Creating and Managing Value in Collaborative Networks, International Journal of Physical Distribution and Logistics Management, issue 3/4, 2004.

synergy, the value proposition of each business unit is likely to be different but complimentary to one another.

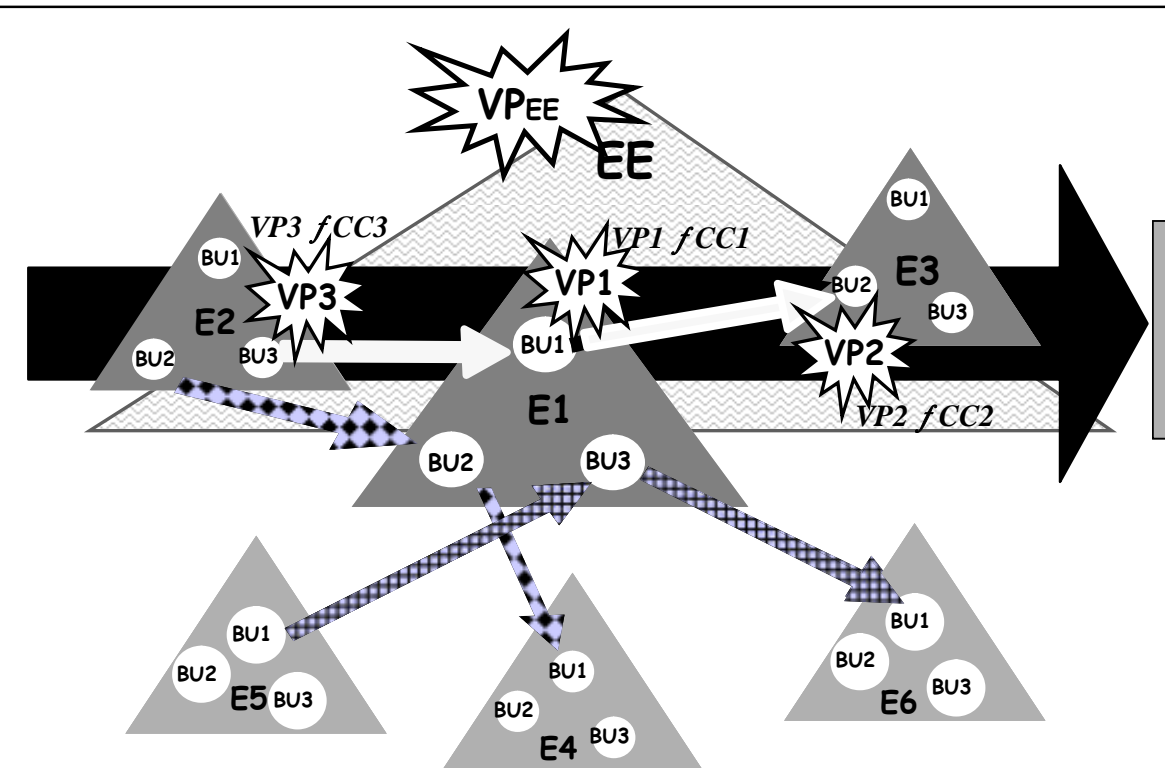

Optimised individual performance Max. overall performance where gains are shared between enterprises

$E=$ Enterprise

EE $=$ Extended Enterprise

VPEE = Value Proposition of the EE
$B U_{i}=$ Business Unit

$V P_{i}=$ Value Proposition of the $B U_{i}$

$C C i=$ Competencies and Capabilities of the BUi

Figure 4. The value proposition in the $\mathrm{EE}$

In summarising this section we could conclude that:

- A single enterprise can have more than one value proposition. i.e. a value proposition for each business unit.

- An enterprise can participate within more than one extended/virtual enterprise

- The individual competencies and capabilities (therefore the value proposition), of each enterprise have strong integration with the value proposition of the overall extended enterprise. 
Bititci, Martinez, Albores and Parung, 2004, Creating and Managing Value in Collaborative Networks, International Journal of Physical Distribution and Logistics Management, issue 3/4, 2004.

- The competencies and capabilities (therefore the value propositions) of each enterprise contribute and support the overall value proposition of the extended enterprise.

- The overall value proposition of the extended enterprise can be different from the value propositions of its members.

- The value proposition of the extended enterprise should be reflected in the kind of value offered to the end customer.

- The value proposition of the extended enterprise is function of the collective competencies and capabilities.

With respect to the literature on value creation, the conclusions relating to value transactions in extended enterprises have lead us identify a three types of value transactions. These are:

- Shareholder value - the value proposition of each enterprise to its shareholders - this is essentially equivalent to internal value as defined in the value creation literature

- Intra-extended-enterprise value proposition $\left(\mathrm{VP}_{\mathrm{En}}\right)$ - the value proposition of each enterprise to the overall extended enterprise. Essentially this represents the value a single member adds to the overall extended enterprise. This is a function of its core competencies and capabilities $\left(\mathrm{CC}_{\mathrm{En}}\right)$ - i.e. $\mathrm{VP}_{\mathrm{En}}=f\left(\mathrm{CC}_{\mathrm{En}}\right)$

- Extended-enterprise value proposition $\left(\mathrm{VP}_{\mathrm{EE}}\right)$ - the value proposition of the extended enterprise to its end-customers. This is a function of the combined competencies and capabilities $\left(\mathrm{CC}_{\mathrm{EE}}\right)$ of the extended enterprise, which is equal or bigger than the sum of the individual members competencies and capabilities $\left(\mathrm{CC}_{\mathrm{En}}\right)$ 
Bititci, Martinez, Albores and Parung, 2004, Creating and Managing Value in Collaborative Networks, International Journal of Physical Distribution and Logistics Management, issue 3/4, 2004.

$$
\mathrm{VP}_{\mathrm{EE}}=f\left(\mathrm{CC}_{\mathrm{EE}}\right) \geq\left[\mathrm{CC}_{\mathrm{E} 1}+\mathrm{CC}_{\mathrm{E} 2}+\mathrm{CC}_{\mathrm{E} 3}\right]
$$

\subsection{Clusters}

A cluster could be define as a network of companies, their customers and suppliers of all the relevant factors, including materials and components, equipment, training, finance and so on (Carrie, 1999). Furthermore, Jones (2002) describes clusters as networks of interdependent firms, knowledge producing institutions, technology providing firms, bridging institutions and customers, linked in a value creating production chain. Clusters are also defined as geographic concentrations of interconnected companies and institutions in a particular field. Clusters encompass an array of linked industries and other entities important to competition. They include, for example, supplier of specialised inputs such as components, machinery, and services, and provides of specialised infrastructure (Porter, 1998).

In clusters, facilitators assist and encourage companies, educational institutes (universities, colleges, etc), consultants, vocational training providers and trade association to collaborate and create more value. Facilitators could be government agencies (as in the Scottish model), volunteers (as in the Arizona model) or executives of the participants (as in the Basque model). The participants such as educational institutions (universities, colleges), consultants, vocational training providers and trade associations, provide specialised training, education, information, research, and technical support to a core group of companies which create value for the entire cluster. The companies collaborate in the cluster with each other by sharing information and 
Bititci, Martinez, Albores and Parung, 2004, Creating and Managing Value in Collaborative Networks, International Journal of Physical Distribution and Logistics Management, issue 3/4, 2004.

integrating similar activities (such as research, education, marketing, IT) in order to achieve better competitive advantages for the members and to support the economic region. These competitive advantages could be:

- Reduce the unit cost by providing technical services to clustered businesses (Porter, 1998; Nolan, 2002)

- Reduced transaction cost because firms and their supplier operate near each other (Nolan, 2002;)

- Integrated research (Bititci and Carrie, 1999; Porter, 1998; Arbonies and Moso, 2002)

- Economies of scale (Carrie, 2000; Nolan, 2002)

- Attractive innovation (Arbonies and Moso, 2002; Scheel, 2002)

- Improved customer service e.g. shorter delivery time because of mutual understanding to help each other between members of the cluster (Carrie, 2000)

- Improved time to market of new products (Carrie, 2000)

- Stronger bargaining power in all respects, including suppliers, government (e.g. built infrastructure, tax incentive) and other relevant bodies (Scheel, 2002)

- Greater scale and presence without sacrificing flexibility (Porter, 1998).

Figure 5 provides a pictorial illustration of a cluster. 
Bititci, Martinez, Albores and Parung, 2004, Creating and Managing Value in Collaborative Networks, International Journal of Physical Distribution and Logistics Management, issue 3/4, 2004.

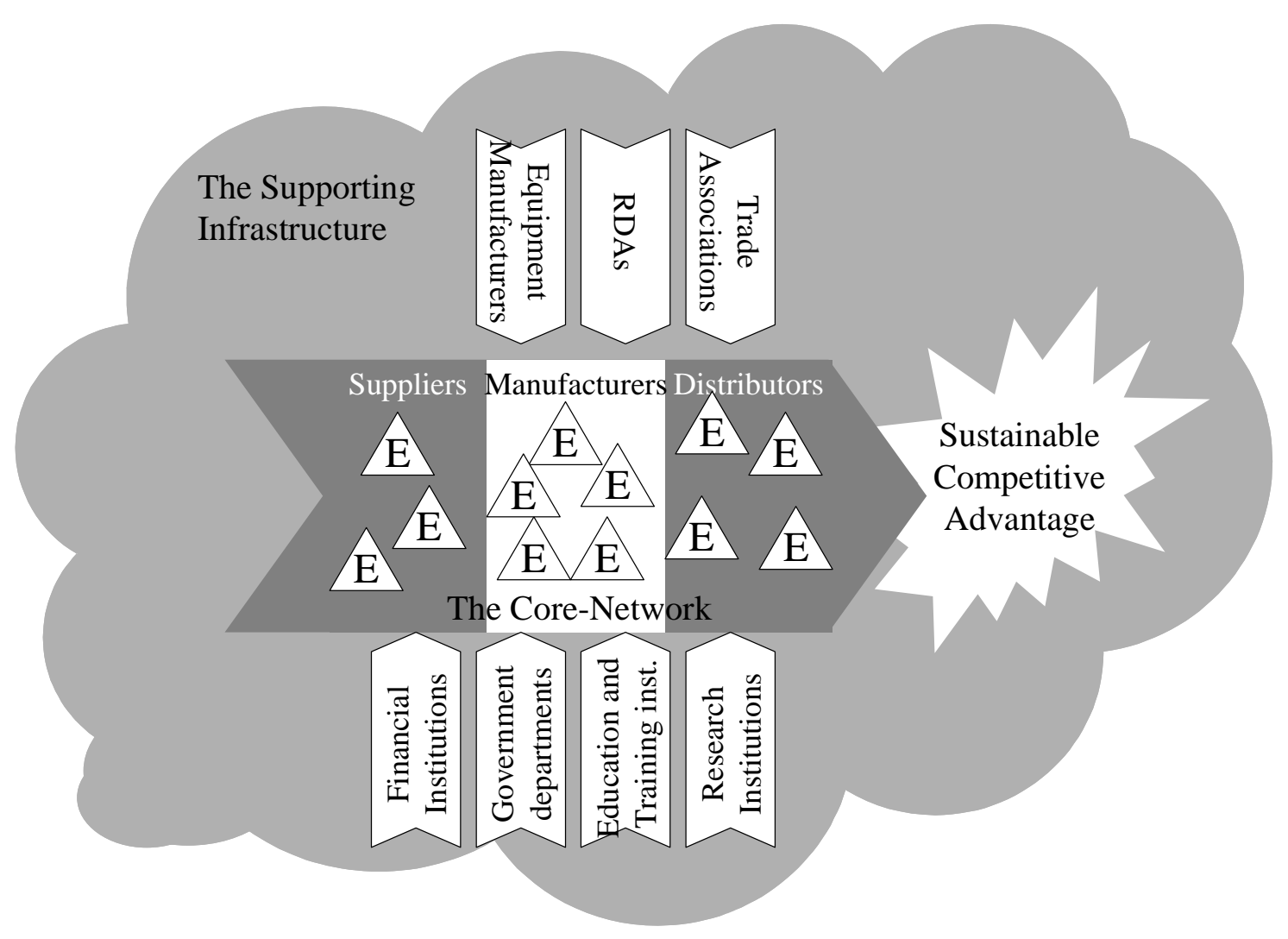

Figure 5. The cluster

Based on the literature on clusters we have at the following conclusions:

- In an extended enterprise there is a higher degree of strategic and operational integration between the members. In a cluster there is a degree of strategic integration within the core-network in order to leverage the support functions but the focus is still on the creation of competitive advantage for each individual enterprise. Therefore strategic synergy and operational integration are not necessary.

- In a cluster each member can leverage the advantages of being a member of the cluster to develop its own competitive advantage by enhancing its competencies and 
Bititci, Martinez, Albores and Parung, 2004, Creating and Managing Value in Collaborative Networks, International Journal of Physical Distribution and Logistics Management, issue 3/4, 2004.

capabilities to develop a unique value propositions for its own target customers and markets.

- Clusters may provide the ideal environment within which extended/virtual enterprises may emerge.

Thus we have identified the following value transactions within a cluster:

- Shareholder value - the value proposition of each member (enterprise or support institution) to its shareholders - this is essentially equivalent to internal value as defined in the value creation literature

- Intra-cluster value proposition $\left(\mathrm{VP}_{\mathrm{ICn}}\right)$ - the value proposition of each member to the overall cluster. Essentially this represents the value a single member adds to the overall cluster. This is a function of its members core competencies and capabilities $\left(\mathrm{CC}_{\mathrm{Mn}}\right)$ - i.e. $\mathrm{VP}_{\mathrm{ICn}}=f\left(\mathrm{CC}_{\mathrm{Mn}}\right)$

- Cluster value proposition $\left(\mathrm{VP}_{\mathrm{C}}\right)$ - the value proposition of the cluster to external markets. This is a function of the combined competencies and capabilities of the cluster $\left(\mathrm{CC}_{\mathrm{C}}\right)$, which is the sum of the individual members competencies and capabilities $\left(\mathrm{CC}_{\mathrm{Mn}}\right)$ - i.e. $\mathrm{VP}_{\mathrm{C}}=f \mathrm{CC}_{\mathrm{C}} \geq\left[\mathrm{CC}_{\mathrm{M} 1}+\mathrm{CC}_{\mathrm{M} 2}+\mathrm{CC}_{\mathrm{M} 3}\right]$. Although, on the surface this sounds similar to the external value proposition for the extended enterprise, it is inherently different. The value proposition of the cluster to its external markets is a structural and infrastructural proposition (e.g. an OEM may wish to form partnerships to purchase its components from an SME which is operating within a good cluster because this structural and infrastructural support available to the SME. Similarly an external investor may be more likely to invest in a venture which is 
Bititci, Martinez, Albores and Parung, 2004, Creating and Managing Value in Collaborative Networks, International Journal of Physical Distribution and Logistics Management, issue 3/4, 2004.

supported by a good cluster). Where as the external-enterprise value proposition is more likely to be a combination of the generic value propositions presented in Figure 1.

- Individual value proposition $\left(\mathrm{VP}_{\mathrm{M}}\right)$ - This is the value proposition of each member to its own customers/markets. This is a function of its own competencies and capabilities $\left(\mathrm{CC}_{\mathrm{Mn}}\right)$ as well as the value proposition of the entire cluster $\left(\mathrm{VP}_{\mathrm{C}}\right)$ - i.e. $\mathrm{VP}_{\mathrm{M}}=f\left[\mathrm{CC}_{\mathrm{Mn}}+\mathrm{VP}_{\mathrm{C}}\right]$

\section{Discussion and Conclusions}

Companies working together are commonly known as collaborative enterprises. From a network point of view, collaborative enterprise or network could be define as: a distinct mode of organisation in which participant organisations work together in equity, commitment and trust exchanging information, sharing activities and resources and complimenting and enhancing each other's capacity for mutual benefit and a common purpose by sharing risks, responsibilities and rewards'.

The research has identified different levels of collaboration and categorised each one of the existing collaborative enterprise models according to the level of collaboration inherent within the network/enterprise, i.e. supply chains, extended and virtual enterprises and clusters. This led us to analyse and identify the value transactions in case of each collaborative enterprise model. 
Bititci, Martinez, Albores and Parung, 2004, Creating and Managing Value in Collaborative Networks, International Journal of Physical Distribution and Logistics Management, issue 3/4, 2004.

According to Jagdev and Thoben (2001), it is not possible to define a single criterion or demarcation to distinguish collaboration in Supply chain, Extended Enterprise and Virtual Enterprise. The same applies to a lesser extend to a cluster. Therefore it is important to identify the key characteristics for each type of collaborative enterprise/network. Table 2 is represents a first attempt at identifying these characteristics and associated value transactions as discussed in greater detail in the paper.

Although the original literature on value creation identified two types of value transaction (Shareholder Value and Customer Value - i.e. the value proposition), in the case of collaborative enterprises/networks, this research has identified additional value transactions. These may be summarised under four different headings as follows:

- Shareholder value - the value proposition of each member to its shareholders - this is essentially equivalent to internal value as defined in the value creation literature.

- Individual value proposition - the value proposition of each member to its endcustomers. This is generally a function of each members' own competencies and capabilities, except in the case of a cluster where members can leverage the capabilities and competencies available in the cluster to enhance their own value propositions to their customers and markets.

- Intra-network value proposition - the value proposition of each member to the overall network. Essentially this represents the value a single member adds (or contribution it 
Bititci, Martinez, Albores and Parung, 2004, Creating and Managing Value in Collaborative Networks, International Journal of Physical Distribution and Logistics Management, issue 3/4, 2004.

makes) to the overall network. This is a function of its core competencies and capabilities.

- Network value proposition - the value proposition of the network to external markets. This is a function of the combined competencies and capabilities of the network but it may be a combination of traditional value propositions in the case of virtual and extended enterprises and a structural and infrastructural value proposition in the case of a supply chain.

This research highlighted the diverse and complicated nature of the value transactions in different types of collaborative enterprises/networks. It is demonstrated that network collaborative enterprises/networks can create a new and unique value propositions by complementing, integrating and leveraging each other's capabilities and competencies.

From a methodological perspective, this is a theoretical paper, which deduced from literature a specific understanding of the interplay between capabilities and competencies and value transactions in collaborative environments. This has resulted in a first-cut model - represented in the form of four value transactions and Table 2 - which should provide a platform for further research in this area. 
Bititci, Martinez, Albores and Parung, 2004, Creating and Managing Value in Collaborative Networks, International Journal of Physical Distribution and Logistics Management, issue 3/4, 2004.

Table 2. Key characteristics and value transactions of collaborative enterprises/networks

\begin{tabular}{|c|c|c|c|c|c|}
\hline & & Supply Chain & Extended Enterprise & Virtual Enterprise & Cluster \\
\hline \multirow{5}{*}{ 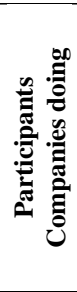 } & Sharing Resources & Low & High & High & Moderate \\
\hline & $\begin{array}{l}\text { Transparency of internal } \\
\text { information }\end{array}$ & Low & High & High & Moderate \\
\hline & Strategic integration & Low & High & High & Moderate \\
\hline & Operational integration & Moderate & High & High & Moderate \\
\hline & Time period of collaboration & Not stated & Long term & Temporary & Long term \\
\hline \multirow{4}{*}{ 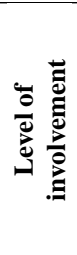 } & Partner enterprises & Low & High & High & Moderate \\
\hline & $\begin{array}{l}\text { Government, regional } \\
\text { development agencies, etc }\end{array}$ & Low & Low & Low & High \\
\hline & $\begin{array}{l}\text { Education and research } \\
\text { Institutes, etc }\end{array}$ & Low & Low & Low & High \\
\hline & $\begin{array}{l}\text { Consultants, Financial } \\
\text { institutions etc }\end{array}$ & Low & Moderate & Moderate & High \\
\hline \multirow{15}{*}{ 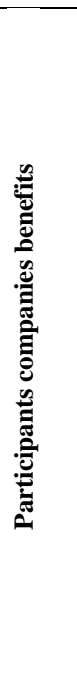 } & Increased market share & Low & High & High & Moderate \\
\hline & Increase asset utilization & Moderate & High & High & Low \\
\hline & Enhanced customer services & Moderate & High & High & Moderate \\
\hline & $\begin{array}{l}\text { Reduced cost of New product } \\
\text { Development (NPD) }\end{array}$ & Low & High & High & Moderate \\
\hline & $\begin{array}{l}\text { Reduce time in product } \\
\text { development }\end{array}$ & Moderate & High & High & Moderate \\
\hline & Decrease risk failure & Low & High & High & Moderate \\
\hline & Increase quality of product & Moderate & High & High & High \\
\hline & Enhanced skill and knowledge & Low & Moderate & Moderate & High \\
\hline & $\begin{array}{l}\text { Enhanced technologies } \\
\text { capabilities }\end{array}$ & Low & Moderate & Moderate & High \\
\hline & $\begin{array}{l}\text { Sharing risk due to the } \\
\text { complexity and rapid rate of } \\
\text { product obsolescence }\end{array}$ & Low & High & High & Low/Moderate \\
\hline & Rapid access to market & Moderate & Moderate & High & High \\
\hline & Economies of scale & Moderate & High & High & High \\
\hline & Reduce order fulfilment time & Moderate & High & High & Moderate \\
\hline & $\begin{array}{l}\text { Rapid response to the } \\
\text { customer's complaint }\end{array}$ & Moderate & High & High & Moderate \\
\hline & Inventory reduction & Moderate & High & High & Moderate \\
\hline \multirow{7}{*}{ 兰 } & Price minimisers & \multirow{6}{*}{ Individual } & \multirow{6}{*}{ Integrated } & \multirow{6}{*}{ Integrated } & \multirow{6}{*}{ Multiple } \\
\hline & Innovators & & & & \\
\hline & Socialisers & & & & \\
\hline & Technology integrator & & & & \\
\hline & Brand manager & & & & \\
\hline & Simplifier & & & & \\
\hline & Structural and Infrastructural & Low & Moderate & Moderate & High \\
\hline \multirow{4}{*}{ 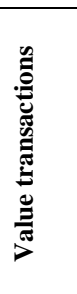 } & Shareholder value & $\checkmark$ & $\checkmark$ & $\checkmark$ & $\checkmark$ \\
\hline & Individual value proposition & $f$ of own $\mathrm{C} \& \mathrm{C}$ & N/a & N/a & $\begin{array}{l}f \text { of own } \mathrm{C} \& \mathrm{C} \\
+ \text { cluster } \mathrm{C} \& \mathrm{C}\end{array}$ \\
\hline & Intra-network value proposition & $f$ of own $C \& C$ & $f$ of own $\mathrm{C} \& \mathrm{C}$ & $f$ of own $C \& C$ & N/a \\
\hline & Network-value proposition & N/a & $\begin{array}{l}f \text { of sum of the } \\
\text { individual C\&C } \\
\text { (Traditional) }\end{array}$ & $\begin{array}{l}f \text { of sum of the } \\
\text { individual C\&C } \\
\text { (Traditional) }\end{array}$ & $\begin{array}{l}f \text { of sum of the } \\
\text { individual C\&C } \\
\text { (Infrastructural) }\end{array}$ \\
\hline
\end{tabular}


Bititci, Martinez, Albores and Parung, 2004, Creating and Managing Value in Collaborative Networks, International Journal of Physical Distribution and Logistics Management, issue 3/4, 2004.

\section{References}

Arbonies, A.L and Moso, M (2002),'Basque Country: The Knowledge Cluster", Journal of Knowledge Management, Vol.6, No.4, pp.347-355, MCB University Press.

Bititci U., Martinez V., Albores P. and Mendibil K. (2003) 'Creating and Sustaining Competitive Advantage in Collaborative Systems: The What? And The How?' Production Planning and Control Journal (Forthcoming).

Bititci, U.S and Carrie, A.S (1998), editors "Strategic management of the Manufacturing Value Chain", IFIP,Kluwer Academic Publishers, Dordrecht, The Netherlands, ISBN 0412-82710-7

Carbo, Bob, Align the Organization for Improved Supply Chain Performance. The ASCET project 4 (2002): 244-447

Carrie, Allan (1999),'Integrated Clusters - the Future Basis of Competition", International Journal of Agile Management Systems, Vol.1 No.1, pp.45-50

Carrie, Allan (2000),"From Integrated Enterprise to Regional cluster: The Changing Basis of Competition", Computers in Industry, Vol. 42, pp. 289-298 Elsevier Science B.V

Childe S.J, 1998, "The extended enterprise- a concept for co-operation", Production Planning and Control, 1998, Vol. 9 No. 4 320-327

Childerhouse, Paul, Aitken, James, and Towill, Denis R., (2002), Analysis and design of focused demand chains. Journal of Operations Management Vol.20 No. 6, 675-689..

Childerhouse, P., Disney, S. M., Lockami III, A. , McCormack, K., And Towill, D. R., (2003), Proven BPR trajectories for effective supply chain change management in Proceedings of the First International Joint Conference EurOMA (European Operations Management Association Conference) - POMS (Production and Operations Management Society): The challenges of integrating research and practice, eds Spina, G., Vineli, A., Cagliano, R., Kalchschmidt, M., Romano, P., And Salvador, F., Vol II, pp 71-80

Darroch, Mark A., Akridge, Jay T., and Boehlje, Michael D., (2002), Capturing value in the supply chain: the case of high oleic acid soybeans. The International Food and Agribusiness Management Review Vol. 5 No.1, 87-103.

Eloranta E, (1999), Keynote Address, International Conference on Advanced Production Management Systems, An IFIP WG5.7 Conference, Berlin, Germany, October 1999.

Holton J.A., (2001),"Building Trust and Collaboration in a Virtual Team", Team Performance Management: An International Journal, Vol.7, No.3-4, pp.36-47, MCB University Press 
Bititci, Martinez, Albores and Parung, 2004, Creating and Managing Value in Collaborative Networks, International Journal of Physical Distribution and Logistics Management, issue 3/4, 2004.

Horvath, Laura, (2001)," Collaboration: The Key to Value Creation in Supply Chain Management", Supply Chain Management: An International Journal, Vol.6, No.5, pp.205-207, MCB University Press.

Huxham, Chris, editor, (1996),"Creating Collaborative Advantage", Saage Publications, London

Jordan Jr. J.A. and Michel F.J.,(2000),'Next Generation Manufacturing: Methods and Techniques",John Wiley \& Sons,Inc.

Jagdev, H.S and Thoben, K.D, (2001),"Anatomy of Enterprise Collaboration", Journal of production Planning \& Control, Vol.12, No.5, pp.437-451.

Kochhar A, and Zhang Y, (2002), "A framework for performance measurement in virtual enterprises", Proceedings of the $2^{\text {nd }}$ International Workshop on Performance Measurement, 6- 7 June 2002, Hanover, Germany, pp 2-11, ISBN 3-00-009491-1.

Lewis, D.J (1990),'Partnership for Profit: Structuring and Managing Strategic Alliances", The Free Press.

Lillehagen F and Karlsen D, (2001), Visual extended enterprise engineering and operation-embedding knowledge management and work execution. Production Planning and Control Vol. 12 No.2, 164-175.

Martinez M. T., Fouletier K. H., and Favrel J., (2001), "Virtual enterprise - organisation, evolution and control", International Journal of Production Economics, vol. 74, pp. 225238.

Martinez, V. and Bititci Umit (2001), "The Value Matrix and its Evolution," Proceedings of the $8^{\text {th }}$ International EurOMA Conference - What really Matters in operations management, Bath UK, 2001. pp 118-130

Martinez, V. (2003) Understanding Value Creation: The Value Matrix and The Value Cube, PhD Thesis Strathclyde University .

McCarthy T.M., Golicic S.L.,(2002),'Implementing Collaborative Forecasting to Improve Supply Chain Performance", International Journal of Physical Distribution \& Logistic Management, Vol.32, No. 6, pp.431-454, MCB University Press.

McLaren T, Head M.,Yuan Y.(2000),"Supply Chain Collaboration Alternatives: Understanding the Expected Cost and Benefits", Internet Research: Electronic Networking Applications and Policy, Vol.12, No.4, pp.348-364

Nolan, A (2002),'Public Policy on Enterprise Clusters and Networks" in Bartlett, W.,Bateman,M., and Vehovec, M.,(editors), Small Enterprise Development: Policies for Sustainable growth in Soth-east Europe, Kluwer Academic Publisher

O'Dell, C. and Grayson, J. (1999) "Knowledge transfer: discover your value proposition" 
Bititci, Martinez, Albores and Parung, 2004, Creating and Managing Value in Collaborative Networks, International Journal of Physical Distribution and Logistics Management, issue 3/4, 2004.

Strategy and Leadership March/April, 10-15.

O’Neill, H. and Sackett, P., 1994, "The Extended Manufacturing Enterprise paradigm", Management Decision, vol. 32, no. 8, pp. 42-49.

Parker, Hamieda (2000),'Inter-firm Collaboration and the New Product Development Process", Industrial Management \& Data Systems, Vol.100, No 6, MCB University Press.

Porter, M.E (1998),"Cluster and the New Economics of Competition”, Harvard Business Review, Nov-Dec, pp.77-90

Rudberg, Martin and Olhager, Jan, Manufacturing networks and supply chains: an operations strategy perspective. Omega Vol. 31; No. 1, 29-39.

Scheel, Carlos, (2002),"Knowledge Clusters of Technological Innovation Systems", Journal of Knowledge Management, Vol.6, No.4, pp.356-367

Treacy M. and Wiersema F. (1996). The disciplines of the market leaders. Publisher Harper Collins. 